\title{
Analysis of Alpine glacier length change records with a macroscopic glacier model
}

\author{
Martin P. Lüthi and Andreas Bauder, Zurich
}

\section{Introduction}

The record of glacier length changes in the Swiss Alps, measured during the last century (GLACIOLOGICAL REPORTS 2009), is unique in its length, its spatial coverage and its variety of glacier geometries. The collective data set contains a wealth of information about past changes in glacier mass balance, and thus climate, albeit in a indirect manner. These data can be viewed as a set of sensors probing climate, where each sensor has a different response to the external forcing.

The position of a glacier terminus depends on two processes: advection of ice into the terminus area, and melting of ice at the surface. If both processes are of the same magnitude, the glacier terminus geometry remains unchanged. Upon a sudden change in mass balance, the terminus geometry reacts immediately due to increased or decreased melting, and with some delay until glacier dynamics changes the mass transport into the terminus area (e.g. NyE 1963). For an oscillating climate, this delay in response depends on the frequency of the mass balance changes, and can be out of phase for frequencies lower than the volume time scale (HutTer 1983; LüTHI 2009; NyE 1965a).

Several studies have used glacier length changes to infer climate history (e.g. KLOK \& OERLEMANS 2003; Nye 1965b; Oerlemans 2001; Oerlemans 2005). STEINER et al. (2005) and STEINER et al. (2008) used reconstructed climate data to drive a neural network trained on a glacier length record to analyze length changes, to infer climate sensitivity, and to predict the future evolution of several glaciers. The studies by HARrison et al. (2003) and OERLEMAns (2007) are quite similar in scope to the present study, although with different approaches to glacier dynamics, and for a considerably smaller number of glaciers.

In this contribution, the length response of 91 glaciers from the data set of glacier length changes from the Swiss Glacier Monitoring Network (GLACIOLOGICAL REPORTS 2009) are analyzed. To this aim, a macroscopic glacier model is used which is formulated as a dynamical system in the variables length and volume (LÜTHI 2009). From the model results, parameters are obtained which are characteristic for these glaciers, the most important of which are the volume time scale as well as constraints on the Little Ice Age equilibrium line history.

\section{Data and methods}

\subsection{Length change data}

The data set of glacier length changes from the Swiss Glacier Monitoring Network is used in this study (Glaciological Reports 2009). This publicly available data set contains 120 glacier length change records with yearly measurements. For 27 glaciers there are time series of more than 100 years, and 3 glaciers have been measured for more than 120 years (Fig. 1). In this study, the length changes for 91 of these glaciers are analyzed, which have a homogeneous data set covering at least 35 years.

\subsection{LV-model}

A macroscopic representation of glacier response to climate is used, formulated as a two-variable dynamical system in the variables «length» $L$ and «volume» $V$ (LÜTHI 2009). The dynamical system reproduces on a macroscopic scale the essential influence of mass balance and ice dynamics on glacier geometry, as represented with the variables $L$ and $V$. Figure 2 illustrates the building blocks of the LV-model: two reservoirs of volumes $V_{A}$ and $V_{B}$ which are linked by a flux element located at horizontal coordinate $G$. The ice flux through a vertical section at the equilibrium line is determined by ice thickness and surface slope according to the shallow-ice approximation (HUTTER 1983). Local mass balance rate is parametrized as a linear function of elevation. From these assumptions, a system of two ordinary differential equations (ODE) can be derived (LüTHI 2009, Eqs. 40)

$$
\begin{aligned}
& \frac{1}{\gamma} \frac{d V}{d t}=V+Z L-\frac{m_{b}}{2} L^{2} \\
& \tau_{a} \frac{d L}{d t}=\left(\frac{V}{a}\right)^{\frac{1}{\mu}}-L
\end{aligned}
$$

where $\gamma=\frac{\partial b}{\partial z}$ is the vertical gradient of mass balance rate (in units of meter ice thickness per year), $m_{b}=\tan \beta$ is bedrock slope, $\tau_{a}$ is the relaxation time constant for the length adjustment, and parameters $a$ and $\mu=7 / 5$ describe the volume-length scaling relation. The scaling parameter $a$ depends explicitly on $\gamma$ and $\beta$ (LÜTHI 2009, Eq. 21). The dynamical system (Eq. 1) contains an external forcing term in $Z(t)=z_{0}-z_{\mathrm{ELA}}(t)$, where $z_{0}$ 
is the highest point of the bedrock (Fig. 2), and $z_{\mathrm{ELA}}(t)$ is the time dependent equilibrium line altitude (ELA). In vicinity of a steady state, the LV-model is equivalent to a linearly damped harmonic oscillator (HARRISON et al. 2003) which is slightly over-damped. The dynamical system (Eq. 1) was solved numerically with the PyDSTool toolkit (CLEWLEY et al. 2004).

\subsection{Equilibrium line history}

In the LV-model, local mass balance rate at the glacier surface is prescribed as a linear function of elevation $b(z)=\gamma\left(z-z_{\mathrm{ELA}}\right)$, with a constant vertical gradient $\gamma$ of local mass balance rate. A changing climate is hence parametrized as a change in ELA, which appears as forcing in the $Z$ term of the LV-model (Eq. 1a). To calculate glacier length changes, a history of ELAs was prescribed, which is based on a reconstructed record of temperature and precipitation of Europe since 1600 (CASTY et al. 2005). A spatial average of monthly data for 9 grid points centered in the Gotthard area was used.

To obtain ELA variations from temperature and precipitation, a bi-linear relation between temperature $T$, precipitation $P$ and ELA was assumed of the form

$$
z_{\mathrm{ELA}}(t)=a+b \Delta T(t)+c\left(1-\frac{\Delta P(t)}{P_{\mathrm{ref}}}\right)
$$

which is equivalent to a standard climate-ELA relation (OHMura et al. 1992, Eq. 1) if the derivatives $\frac{\partial T}{\partial z}$ and $\frac{\partial P}{\partial T}$ are constant. The values of the constants were determined by fitting the parametrized ELA changes to reconstructed ELA variations for several Swiss glaciers (Huss et al. 2008; Huss 2009). The best agreement between the climate and ELA reconstructions was found for summer (JJA) temperature, and yearly average precipitation, with the constants $a=$ $2738 \mathrm{~m}, b=101 \mathrm{~m} \mathrm{~K}^{-1}, c=200 \mathrm{~m}$ and $P_{\text {ref }}=2000 \mathrm{~mm}$.

As will be shown below, the ELA reconstruction is not suitable to produce any of the big and rapid Little Ice Age glacier advances observed between 1650 and 1850 . To achieve a match of measured length changes before 1910, the ELA had to be lowered by 100 to $200 \mathrm{~m}$ for certain periods within the time span 1650 to 1850 .

\section{Model results}

The response of a glacier to climate forcing depends on its geometry, which in the LV-model is simply parametrized as bedrock slope $\beta$ and vertical extent $Z$ of the accumulation area. Driven by a history of ELA changes, glacier length changes were calculated with

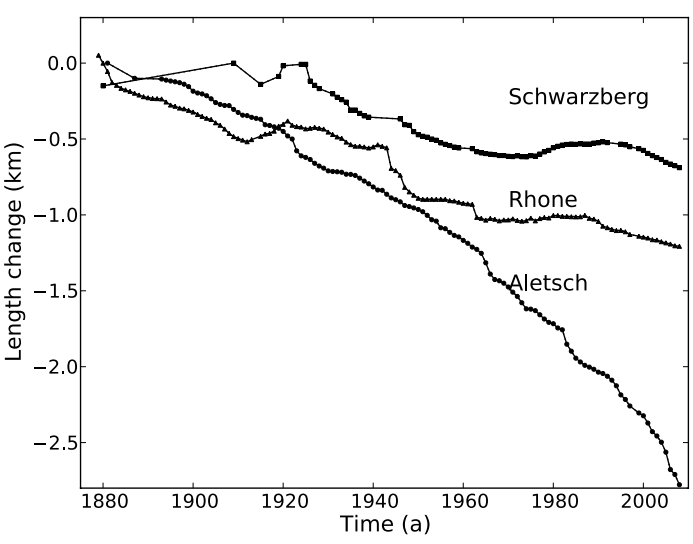

Fig. 1: Length changes of three glaciers of different length and mean slope and with a length change record exceeding 100 years: Grosser Aletschgletscher, Rhonegletscher, Schwarzberggletscher.

Längenänderungen von drei Gletschern mitunterschiedlicher Länge und mittlerer Neigung, deren Messdaten mehr als 100 Jahre abdecken: Grosser Aletschgletscher, Rhonegletscher, Schwarzberggletscher.

Variations de longueur de trois glaciers présentant des longueurs et des pentes différentes sur une période de plus de 100 ans: glacier d'Aletsch, glacier du Rhône et Schwarzberggletscher.

the LV-model in the following manner: The model glaciers were initialized to a steady state in the year 1600 for each set of parameters $\gamma, \beta$ and $Z$. The model was driven with an ELA history calculated from temperature and precipitation from the climate reconstruction (Eq. 2). The ELA history used for the time span after 1880 is shown in Figure 3c, and the complete history in Figure 4b.

The influence of the geometry parameters on glacier length response is investigated in Figure 3. The ELA history shown in panel $3 \mathrm{c}$ was used to drive the LVmodel (Eq. 1) for different values of $\beta$ (Figure 3a) and $Z$ (Figure $3 b$ ). It is immediately obvious that flat glaciers and glaciers with a small vertical extent show a very smooth response, and therefore have long response times. On the other hand, steep glaciers, and glaciers spanning a high elevation difference show a large and fast response to short-term fluctuations of the ELA.

The model results in Figure 3 look similar in character to the measured length change records from the data set (Figure 1). For a quantitative comparison, an optimization procedure was used to find a set of model parameters $(\gamma, Z, \beta)$ which produces the best-match- 


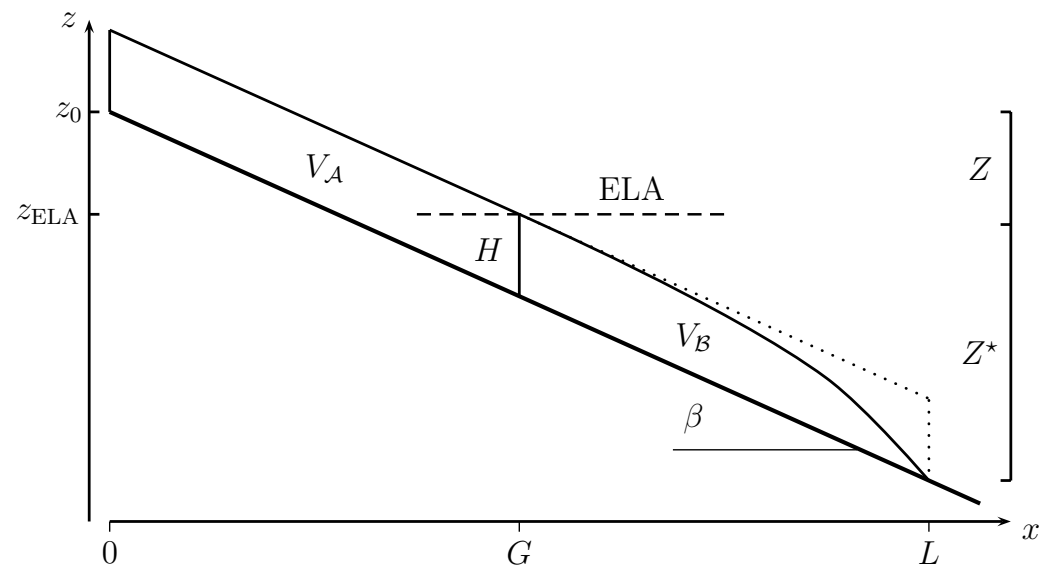

Fig. 2: A sketch of the LV-model geometry and relevant quantities Skizze der Geometrie des LV-Modells und der geometrischen Grössen Croquis de la géométrie du modèle $L V$ et des tailles géométriques

ing length change history. With a set of parameters, the dynamical system was integrated forward in time for each of the ELA histories shown in Figure 4b as driving function (many more unsuccessful attempts are not shown). Each of the measured length change records was then compared to the responses of the model glaciers to find the closest match between real and model glaciers. The best overall agreement was obtained with $\gamma=0.008 \mathrm{a}^{-1}$, which was adopted for all glaciers. The best fitting model glacier then yields the characteristic parameters $Z$ and $\beta$, and from these the derived quantities «model glacier length» $L$ and «volume time scale» $\tau_{v}$ can be determined.

The modeled glacier response is strongly influenced by the climate history assumed between 1650 and 1850, a climatic episode termed the «Little Ice Age»(LIA). For most glaciers, especially those with a long response time, it is impossible to obtain a reasonable fit between modeled and measured length changes if the model is forced with ELA variations according to the climate reconstruction of precipitation and temperature alone. Since mass balance also depends on variation of solar radiation (e.g. Huss et al. 2009), and inspired by the reconstruction of the radiative forcing for the time span considered (e.g. Crowley 2000; STEINHILber et al. 2009), the ELA was lowered during certain phases of the LIA. Taking Grosser Aletschgletscher as an example, Figure 4 shows the modeled response for three different LIA climates which differ only by a constant offset of the ELA during certain time spans. A reasonable agreement for the length change records of most glaciers could be obtained for an ELA low- ered by $100 \mathrm{~m}$ between 1680 and 1720 , and by $150 \mathrm{~m}$ between 1800 and 1850 (solid line in Figure 4b), which was adopted for the rest of this study.

Length change data for 91 glaciers of the Swiss Glacier Monitoring Network contain enough homogeneous data points to be fitted with modeled length changes. These best-fitting model glaciers capture the essential dynamics of a glacier terminus, and yield values for $\beta$, $Z$ and the volume time scale $\tau_{v}$. Figure 5 shows how well the individual glacier length records could be fitted with the LV-model. Table 1 lists characteristic quantities and model parameters for the glaciers. Also listed are inferred volume time scales which range from 5-20 years for very steep glaciers (e.g. Rosenlaui, Orny, Trient), 130-140 years for Grosser Aletschgletscher, and up to 160-180 years for several smaller glaciers. The increasingly large uncertainties of determined volume time scale for longer-timescale glaciers is due to the relatively short sampling interval of glacier response, as compared to the volume time scale.

The method works surprisingly well even for glaciers that would appear as problematic: heavily debris-covered glacier tongues (e.g. Unteraar, Zmutt; whereas Mont Durand cannot be fitted), glaciers that went through a strong topographic break during the sampling interval (e.g. Blüemlisalp, Eiger, Palü, Rhone, Tiatscha, Turtmann; whereas Mont Fort cannot be fitted), and glaciers that were affected by hydraulic dams (Unteraar, Oberaar, Gries) and natural lakes (Roseg, Gauli, Trift), where formation of a proglacial lake lead to temporarily fast retreat. 


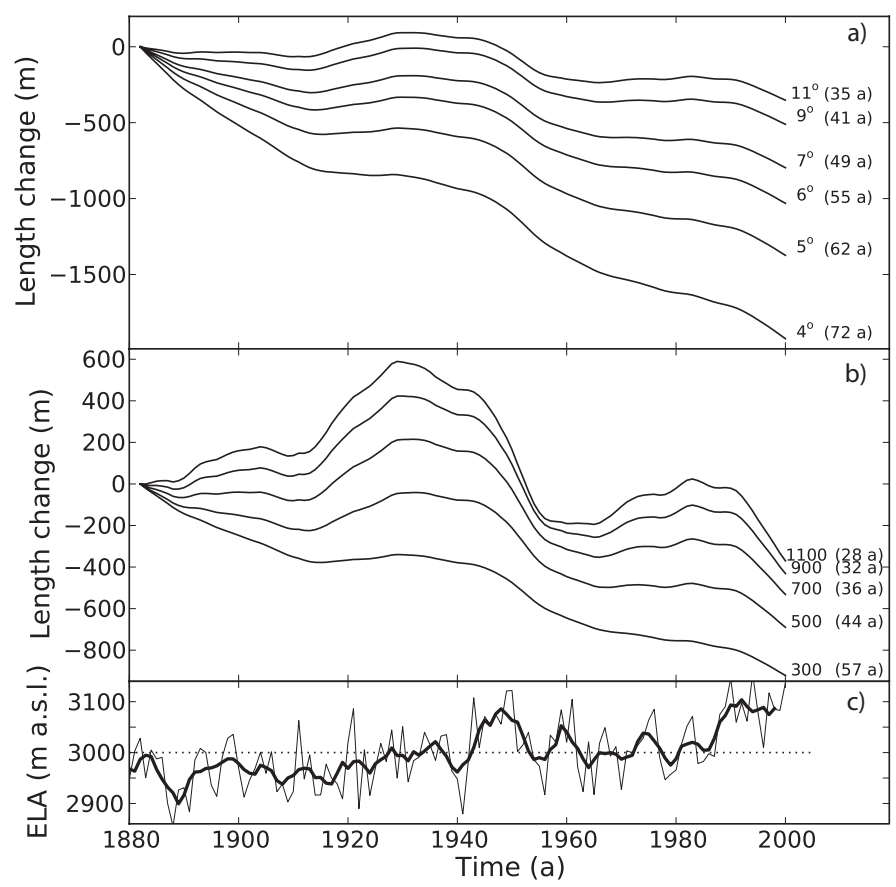

Fig. 3: Modeled length changes for glaciers of (a) different bedrock slopes $\beta$ (for $Z=400 \mathrm{~m}$ ) and (b) different vertical extents $Z$ of the accumulation area (for $\beta=7^{\circ}$ ). Values of $\beta$ and $Z$ are indicated next to curves, the volume time scale $\tau_{v}$ is given in parentheses. (c) The variation of equilibrium line altitude is shown as a thin line, and smoothed with a 5 years running average (wide line).

Modellierte Längenänderungen von Gletschern für (a) verschiedene Bettneigungen $\beta$ (für $Z=400 \mathrm{~m}$ ) und (b) für verschiedene vertikale Ausdehnungen des Akkumulationsgebietes $Z$ (für $\beta=7^{\circ}$ ). Werte von $\beta$ oder $Z$ sowie die Volumenzeitskala $\tau_{v}$ (in Klammern) sind neben den Kurven angegeben. (c) Die Variation der Gleichgewichtslinie ist als dünne, das 5-Jahres-Mittel als dicke Linie dargestellt.

Modélisation des changements de longueur des glaciers présentant (a) différentes pentes du soubassement rocheux $\beta$ (pour $Z=400 \mathrm{~m}$ ) et (b) différentes extensions verticales de la zone d'accumulation (pour $\beta=7^{\circ}$ ). Les valeurs de $\beta$ et de $Z$ sont indiquées à côté des courbes, l'échelle temporelle $\tau_{v}$ est indiquée entre parenthèses. (c) La variation de l'altitude de la ligne d'équilibre est indiquée par une ligne fine tandis qu'une ligne épaisse indique des valeurs lissées avec une moyenne mobile de 5 ans.

\section{Discussion}

One cannot expect a perfect fit between modeled and measured length changes for several reasons. The assumed model geometry with an uniformly inclined bedrock is too simple to reproduce glacier length changes if they occur in a terrain with strong topographic changes, such as steps or changing valley widths in the terminus area. It is, however, astonishing that for most glaciers a simple model glacier can be found which has a similar length change response. The determined geometrical parameters $\beta$ and $Z$ (Table 1) are often surprisingly close to the real geometry, where $\beta$ should be interpreted as mean slope of the ablation area. The accumulation area is poorly represented in the LV-model since the usual flow convergence from a wide accumulation area, and the often constant accumulation rate at higher elevations, are neglected. Nevertheless, the essential features of the LV-model, namely the total mass flux from the accumulation area to the ablation area, and the constant mass balance gradient in an ablation area of constant width, seem like realistic approximations.

\subsection{Volume time scale}

How fast and to what extent a glacier reacts to changes in climate is largely determined by a single parameter, the volume time scale $\tau_{v}$ (HARRISON et al. 2001; JóHAN- 


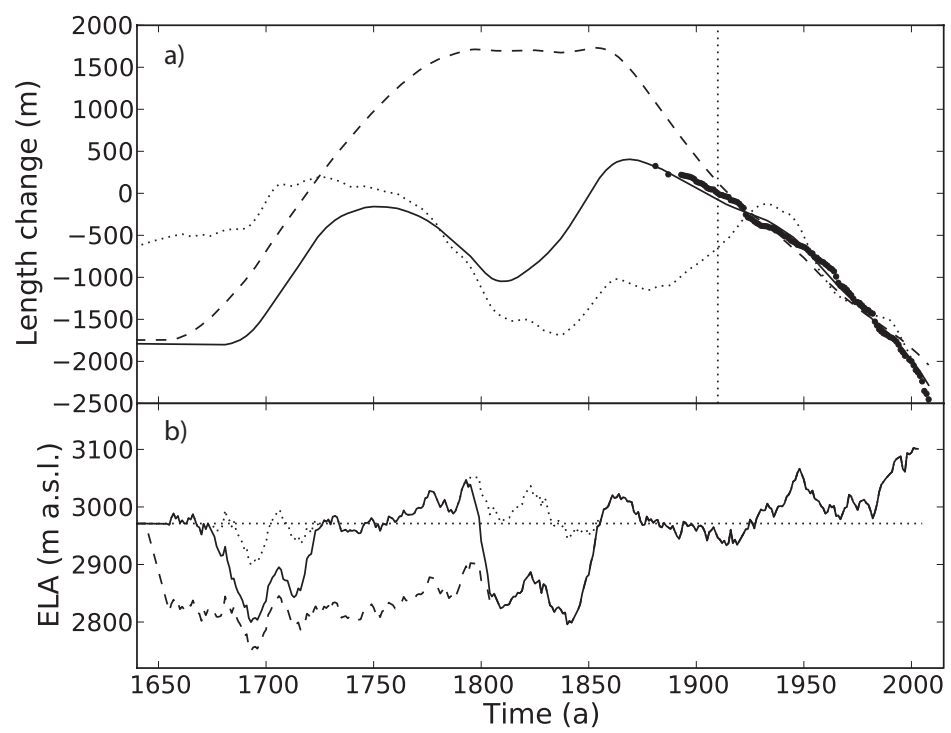

Fig. 4: (a) Length changes of a model glacier that fits the measured length changes of Grosser Aletschgletscher (dots). Dotted line corresponds to a climate reconstruction alone, dashed and solid lines indicate altered ELA histories. (b) The three climate scenarios, plotted as 11-year smoothed ELA variations, which were used to drive the LV-model.

(a) Längenänderungen von Modellgletschern, die die gemessenen Längenänderungen des Grossen Aletschgletschers reproduzieren (Punkte). Die gepunktete Linie ist das Resultat, das auf der Klimarekonstruktion basiert, die durchbrochene und die durchgezogene Linie wurden mit veränderten Klimageschichten berechnet. (b) Die drei Klimageschichten, dargestellt als 11-Jahres-Mittel der Gleichgewichtslinie, welche als Antrieb für das LV-Modell gebraucht wurden.

Variations de longueur d'un glacier modélisé correspondant aux variations enregistrées sur le glacier d'Aletsch (points). Les lignes en pointillés sont basées sur une reconstruction climatique unique, tandis que les lignes discontinues et continues indiquent des antécédents climatiques de la ligne d'équilibre (ELA) altérés. (b) Les trois scénarios climatiques utilisés dans le modèle LV sont montrés ici avec un lissage de 11 ans de la variation d'altitude de la ligne d'équilibre (ELA).

NESSON et al. 1989; ). The volume time scale depends on a combination of geometric parameters, and is inversely proportional to the mass balance gradient $\gamma$ (HARRISON et al. 2003; LÜTHI 2009)

$$
\tau_{v}:=-\left(\gamma+\frac{b_{L}}{H_{e}}\right)^{-1}=\frac{H_{e}}{\left(-b_{L}\right)-\gamma H_{e}} .
$$

The volume time scale depends on the balance rate at the terminus $b_{L}=\gamma\left(z_{0}-m_{b} L-z_{\mathrm{ELA}}\right)=\gamma\left(Z-m_{b} L\right)$, and on the effective ice thickness $H_{e}=(d L / d V)^{-1}$ which is the slope of the length-volume relationship of steady state glaciers.

Volume time scales for steady state glaciers are shown as function of $\beta$ and $Z$ in Figure 6 for a mass balance gradient $\gamma=0.008 \mathrm{a}^{-1}$, which is typical for Alpine glaciers. The figure shows that long volume time scales should be expected for flat glaciers with little elevation difference. Short volume time scales, and therefore rapid reaction to climate change, are expected for steep glaciers and high elevation difference. Also indicated in Figure 6 are the names of the best-fitting model glaciers, plotted at the location of the model parameters.

It is noteworthy, that not only long glaciers (Grosser Aletschgletscher, Gorner, Otemma) have a long volume time scale, but also several smaller glaciers (e.g. Paradies, Roseg, Cheillon). The theory used to derive the LV-model explains that the volume time scale depends only on the "activity index» $\zeta$ like $\tau_{v}^{-1}=$ $\gamma(\zeta-1)$ (LÜTHI 2009). This parameter, defined by

$$
\zeta:=\frac{Z^{*}}{H_{e}}=\frac{m_{b} L-Z}{\mu f H}>0,
$$



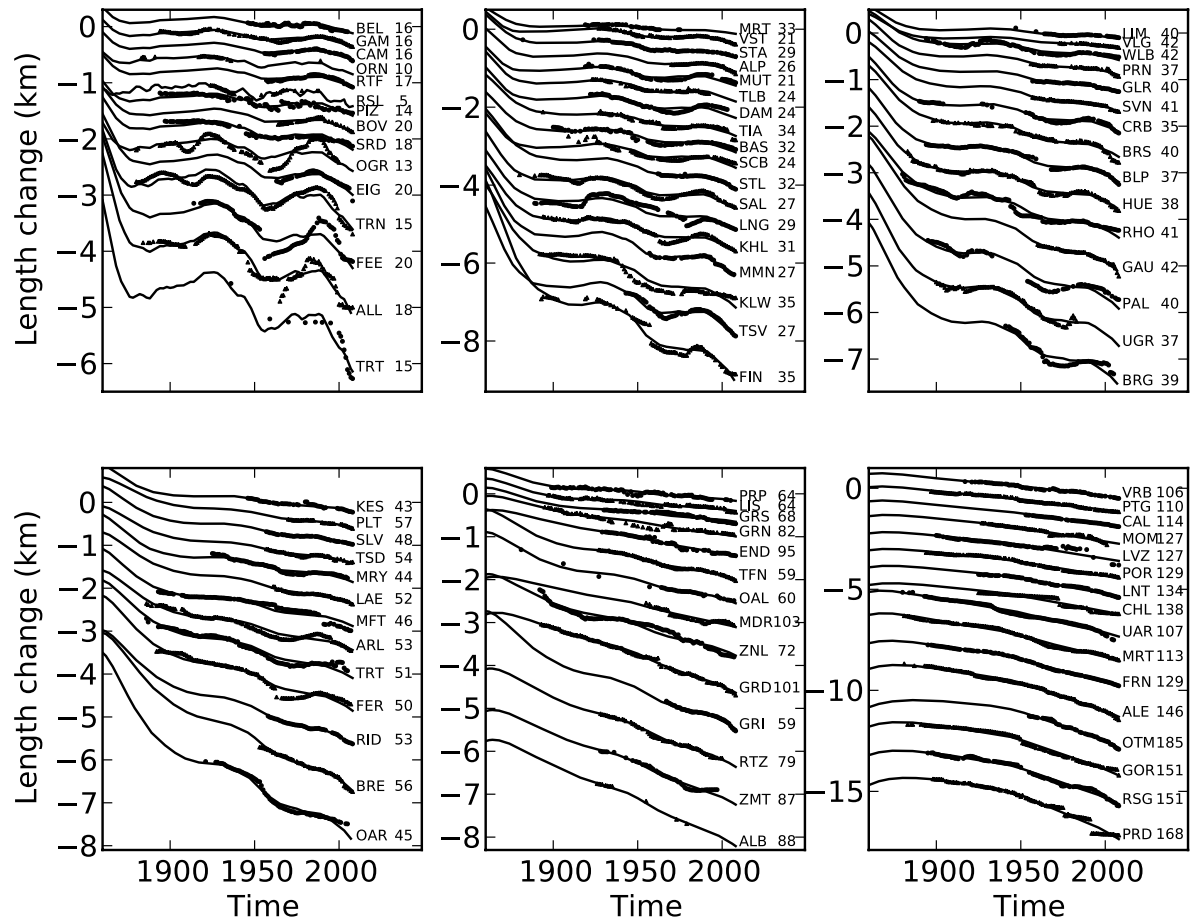

Fig. 5: Modeled length changes under the same climate are shown for 91 glaciers with solid lines (vertically shifted for clarity). Measured length changes are indicated with dots. At the end of each line, the 3 letter abbreviation of the glacier name (cf. Table 1) and the volume time scale are given.

Modellierte Längenänderungen für 91 Gletscher wurden mit der gleichen Klimageschichte als Antrieb berechnet (die Kurven sind der Übersichtlichkeit halber vertikal verschoben). Gemessene Längen sind mit Punkten dargestellt. Am Ende jeder Linie sind ein Kürzel des Gletschernamens (Tabelle 1) sowie die Volumenzeitskala angegeben.

Les lignes indiquent les variations de longueur modélisées pour 91 glaciers sur la base d'un climat identique (rendues verticales pour plus de clarté). Les variations de longueur mesurées sont indiquées par des points. A la fin de chaque ligne figurent les abréviations des noms des glaciers (voir Tableau 1) ainsi que l'échelle de temps.

only depends on geometric quantities, and parameters from the scaling relation $(\mu)$ and self-similarity $(f)$, and can be visualized as the vertical extent of the ablation area $Z^{*}$ scaled by the effective ice thickness $H_{e} \sim$ $1.23 H$ (shown in Fig. 2).

\subsection{Climate}

The glacier length variations during the last 150 years of all 91 investigated glaciers can be explained with a single history of ELA variation, and a constant mass balance gradient of $\gamma=0.008 \mathrm{a}^{-1}$. The similar variation of the ELA throughout the whole Swiss Alps, despite large differences in local climate, is attributable to the strong dependence of ELA on temperature. Air temperature anomalies are well correlated in the Alpine area (e.g. CASTY et al. 2005).
The measured glacier length changes could only be reproduced with the LV-model if the ELA history (calculated from a reconstructed temperature and precipitation history) was considerably altered during certain periods of the LIA. The marked advance of most glaciers between 1830 and 1850 cannot be reproduced without such an ELA alteration.

The necessity to alter the ELA-history can have several reasons:

- Reconstructed air temperature and precipitation rely mainly on data from low elevation stations, especially before the $20^{\text {th }}$ century, which might result in a misrepresentation of the reconstructed climate at high elevations.

- The time spans of altered ELA correspond to phases 


\begin{tabular}{|c|c|c|c|c|c|c|c|c|}
\hline Name & Short & Length & Time span & \#meas. & $\beta$ & $Z$ & $\zeta$ & $\tau_{v}$ \\
\hline Rosenlaui & RSL & 5.2 & $1923-1988$ & 27 & 41.5 & 1750 & 27.37 & 5 \\
\hline Orny & ORN & 2.9 & $1881-1989$ & 22 & 41.3 & 483 & 13.27 & 10 \\
\hline Ob. Grindelwald & OGR & 6.7 & $1878-2000$ & 98 & 25.2 & 741 & 10.67 & 12 \\
\hline Pizol & PIZ & 0.6 & $1892-2008$ & 95 & 33.3 & 416 & 9.97 & 13 \\
\hline Trient & TRN & 4.9 & $1878-2008$ & 128 & 13.8 & 1450 & 9.61 & 14 \\
\hline Trift & TRT & 5.8 & $1860-2008$ & 17 & 8.2 & 2700 & 9.24 & 15 \\
\hline Bella Tola & BEL & 0.6 & $1944-2005$ & 57 & 40.0 & 250 & 9.06 & 15 \\
\hline Cambrena & CAM & 1.9 & $1955-2008$ & 46 & 39.0 & 250 & 8.84 & 15 \\
\hline Gamchi & GAM & 2.8 & $1893-2008$ & 101 & 39.0 & 250 & 8.84 & 15 \\
\hline Rotfirn & RTF & 2.1 & $1955-2008$ & 50 & 36.5 & 250 & 8.31 & 17 \\
\hline Sardona & SRD & 0.7 & $1894-2008$ & 94 & 24.8 & 450 & 8.13 & 17 \\
\hline Allalin & ALL & 6.5 & $1880-2008$ & 114 & 9.0 & 1733 & 7.83 & 18 \\
\hline Boveyre & BOV & 2.6 & $1963-2008$ & 37 & 28.8 & 300 & 7.47 & 19 \\
\hline Fee & FEE & 5.0 & $1913-2008$ & 86 & 11.0 & 1150 & 7.31 & 19 \\
\hline Eiger & EIG & 2.6 & $1962-2008$ & 43 & 17.0 & 625 & 7.29 & 19 \\
\hline Verstankla & VST & 2.1 & $1925-2008$ & 71 & 27.8 & 275 & 6.95 & 21 \\
\hline Mutt & MUT & 1.0 & $1917-2008$ & 70 & 24.0 & 341 & 6.93 & 21 \\
\hline Tälliboden & TLB & 0.8 & 1921 - 1992 & 56 & 19.2 & 383 & 6.27 & 23 \\
\hline Schwarzberg & SCB & 3.8 & $1879-2008$ & 77 & 17.8 & 425 & 6.23 & 23 \\
\hline Damma & DAM & 2.4 & $1920-2003$ & 80 & 18.8 & 375 & 6.09 & 24 \\
\hline Alpetli & ALP & 6.8 & $1969-2008$ & 39 & 21.8 & 275 & 5.82 & 25 \\
\hline Saleina & SAL & 6.5 & $1877-2008$ & 116 & 12.9 & 558 & 5.74 & 26 \\
\hline Mont Miné & MMN & 8.3 & 1955 - 2007 & 44 & 9.2 & 866 & 5.67 & 26 \\
\hline Tschierva & TSV & 4.8 & $1933-2008$ & 63 & 7.7 & 1041 & 5.52 & 27 \\
\hline Sankt Anna & STA & 0.8 & $1866-2008$ & 75 & 21.5 & 225 & 5.27 & 29 \\
\hline Lang & LNG & 6.9 & $1887-2008$ & 109 & 12.2 & 500 & 5.26 & 29 \\
\hline Basodino & BAS & 1.5 & $1898-2008$ & 84 & 15.8 & 316 & 5.05 & 30 \\
\hline Kehlen & KHL & 2.6 & $1892-2008$ & 107 & 11.2 & 500 & 5.01 & 31 \\
\hline Steinlimmi & STL & 2.8 & $1960-2008$ & 47 & 12.0 & 425 & 4.85 & 32 \\
\hline Martinets & MRT & 1.9 & $1918-1975$ & 37 & 32.0 & 100 & 4.83 & 32 \\
\hline Kaltwasser & KLW & 1.6 & $1890-2008$ & 102 & 7.8 & 700 & 4.65 & 34 \\
\hline Findelen & FIN & 7.8 & $1892-2008$ & 79 & 4.8 & 1350 & 4.65 & 34 \\
\hline Tiatscha & TIA & 2.0 & $1893-2008$ & 71 & 15.2 & 275 & 4.63 & 34 \\
\hline Blümlisalp & BLP & 2.7 & $1892-2008$ & 101 & 11.7 & 366 & 4.47 & 36 \\
\hline Corbassière & CRB & 10.2 & $1888-2008$ & 71 & 14.8 & 258 & 4.44 & 36 \\
\hline Paradisino & PRN & 1.1 & $1954-2008$ & 41 & 19.2 & 175 & 4.40 & 36 \\
\hline Unt. Grindelwald & UGR & 8.3 & $1899-1983$ & 82 & 7.3 & 633 & 4.32 & 37 \\
\hline Hüfi & HUE & 7.1 & $1881-2008$ & 116 & 10.7 & 375 & 4.29 & 38 \\
\hline Brunegg & BRG & 4.6 & $1933-2005$ & 65 & 6.8 & 675 & 4.23 & 38 \\
\hline Bresciana & BRS & 1.1 & $1895-2008$ & 81 & 11.8 & 308 & 4.19 & 39 \\
\hline Palü & PAL & 3.8 & $1893-2008$ & 76 & 7.5 & 550 & 4.12 & 40 \\
\hline Glärnisch & GLR & 2.5 & $1956-2008$ & 48 & 17.2 & 175 & 4.12 & 40 \\
\hline Rhone & RHO & 8.0 & $1878-2008$ & 128 & 9.9 & 375 & 4.11 & 40 \\
\hline Limmern & LIM & 3.1 & $1944-2008$ & 44 & 29.8 & 75 & 4.07 & 40 \\
\hline Wallenbur & WLB & 1.9 & $1892-2008$ & 101 & 20.8 & 125 & 4.00 & 41 \\
\hline Valleggia & VLG & 0.9 & $1970-2008$ & 29 & 28.5 & 75 & 3.95 & 42 \\
\hline Sesvenna & SVN & 1.2 & $1955-2008$ & 49 & 15.0 & 191 & 3.95 & 42 \\
\hline Gauli & GAU & 6.5 & 1957 - 2008 & 47 & 7.8 & 458 & 3.92 & 42 \\
\hline Moiry & MRY & 5.3 & $1924-2005$ & 79 & 13.9 & 208 & 3.92 & 42 \\
\hline Kessjen & KES & 0.9 & $1945-2008$ & 50 & 19.8 & 125 & 3.89 & 43 \\
\hline Oberaar & OAR & 5.0 & $1920-2005$ & 76 & 5.0 & 750 & 3.75 & 45 \\
\hline Mont Fort & MFT & 2.1 & $1891-2007$ & 103 & 12.2 & 216 & 3.70 & 46 \\
\hline Silvretta & SLV & 3.3 & $1956-2008$ & 49 & 15.2 & 150 & 3.62 & 47 \\
\hline Ferpecle & FER & 6.6 & $1890-2007$ & 111 & 7.8 & 350 & 3.51 & 49 \\
\hline Turtmann & TRT & 5.8 & $1884-2005$ & 114 & 9.0 & 275 & 3.46 & 50 \\
\hline
\end{tabular}




\begin{tabular}{|c|c|c|c|c|c|c|c|c|}
\hline Name & Short & Length & Time span & \#meas. & $\beta$ & $Z$ & $\zeta$ & $\tau_{v}$ \\
\hline Ried & RID & 6.3 & $1957-2008$ & 47 & 7.5 & 325 & 3.36 & 52 \\
\hline Arolla & ARL & 4.8 & $1885-2007$ & 114 & 10.7 & 200 & 3.35 & $50-56$ \\
\hline Tseudet & TSD & 3.0 & $1956-2008$ & 46 & 14.8 & 125 & 3.33 & 53 \\
\hline Lämmern & LAE & 2.6 & $1960-2008$ & 48 & 11.9 & 166 & 3.31 & 54 \\
\hline Breney & BRE & 6.0 & $1952-2008$ & 52 & 5.2 & 475 & 3.24 & 55 \\
\hline Tiefen & TFN & 3.0 & $1926-2008$ & 78 & 11.3 & 166 & 3.24 & $53-59$ \\
\hline Plattalva & PLT & 1.4 & $1968-2008$ & 32 & 16.0 & 100 & 3.20 & 56 \\
\hline Gries & GRI & 5.7 & $1966-2008$ & 42 & 6.8 & 300 & 3.11 & $56-61$ \\
\hline Lischana & LIS & 0.9 & $1894-2008$ & 84 & 22.2 & 50 & 2.97 & 63 \\
\hline Prapio & PRP & 0.8 & $1897-2005$ & 84 & 22.2 & 50 & 2.97 & 63 \\
\hline Oberaletsch & OAL & 9.1 & $1869-2007$ & 40 & 10.9 & 133 & 2.95 & $60-66$ \\
\hline Griess & GRS & 1.6 & $1928-2008$ & 71 & 20.2 & 50 & 2.84 & 68 \\
\hline Zinal & ZNL & 7.5 & $1890-2007$ & 114 & 8.5 & 150 & 2.74 & $66-78$ \\
\hline Rätzli & RTZ & 5.2 & $1924-2000$ & 63 & 6.6 & 175 & 2.59 & $72-84$ \\
\hline Griessen & GRN & 1.2 & $1893-2007$ & 75 & 15.2 & 50 & 2.52 & 82 \\
\hline Zmutt & ZMT & 6.7 & $1927-1997$ & 54 & 6.2 & 150 & 2.44 & $80-94$ \\
\hline Albigna & ALB & 3.7 & $1905-1979$ & 13 & 5.4 & 175 & 2.41 & $82-96$ \\
\hline Lavaz & LVZ & 2.1 & $1899-2008$ & 80 & 7.9 & 108 & 2.43 & $66-126$ \\
\hline Endarrey & END & 2.1 & $1879-2008$ & 66 & 12.0 & 50 & 2.31 & 95 \\
\hline Grand Desert & GRD & 2.2 & $1891-2008$ & 108 & 6.5 & 108 & 2.28 & $89-103$ \\
\hline Vorab & VRB & 2.0 & $1916-2008$ & 69 & 10.2 & 58 & 2.27 & $87-105$ \\
\hline Mont Durand & MDR & 5.9 & $1954-2007$ & 49 & 10.5 & 50 & 2.21 & 103 \\
\hline Unteraar & UAR & 12.9 & $1875-2005$ & 114 & 5.0 & 133 & 2.20 & $96-109$ \\
\hline Moming & MOM & 3.6 & 1926 - 2001 & 68 & 7.4 & 83 & 2.23 & $82-126$ \\
\hline Calderas & CAL & 1.8 & $1952-2008$ & 52 & 8.8 & 58 & 2.17 & $96-113$ \\
\hline Punteglias & PTG & 1.4 & $1894-2008$ & 100 & 9.2 & 50 & 2.13 & 110 \\
\hline Morteratsch & MRT & 7.0 & 1877 - 2008 & 122 & 4.5 & 116 & 2.08 & $109-125$ \\
\hline Forno & FRN & 6.2 & $1894-2008$ & 97 & 4.2 & 108 & 2.02 & $112-129$ \\
\hline Porchabella & POR & 2.4 & $1892-2008$ & 100 & 6.8 & 50 & 1.97 & 129 \\
\hline Lenta & LNT & 2.6 & $1924-2008$ & 73 & 6.2 & 50 & 1.94 & 133 \\
\hline Grosser Aletsch & ALE & 23.9 & $1869-2008$ & 118 & 3.2 & 116 & 1.93 & $127-146$ \\
\hline Cheillon & $\mathrm{CHL}$ & 3.7 & $1923-2008$ & 79 & 5.8 & 50 & 1.90 & $135-141$ \\
\hline Gorner & GOR & 13.5 & $1881-2008$ & 112 & 2.8 & 100 & 1.84 & 149 \\
\hline Roseg & RSG & 4.9 & $1894-2008$ & 100 & 2.7 & 91 & 1.80 & $150-167$ \\
\hline Paradies & PRD & 3.6 & $1872-2008$ & 99 & 2.2 & 116 & 1.79 & $152-167$ \\
\hline Otemma & OTM & 8.7 & $1954-2008$ & 48 & 2.3 & 66 & 1.72 & $156-185$ \\
\hline
\end{tabular}

Tab. 1: Volume time scales for 91 glaciers as inferred from the model results. Given are glacier name, 3 letter abbreviation, length in the year 1973 (in km; MAISCH 2001), time span and number of measurements used, the values of model parameters $\beta, Z$ and $\zeta$, and the volume time scale.

Volumenzeitskalen für 91 Gletscher, bestimmt aus den Modell-Resultaten. Angegeben sind: Gletschername, Kürzel, Länge im Jahr 1973 (in km; MAIscH 2001), Zeitspanne und Anzahl Messungen, Werte der Modellparameter $\beta, Z$ und $\zeta$ sowie die Volumenzeitskala.

Echelles de temps pour 91 glaciers tel qu'estimé par le modèle. Sont indiqués le nom des glaciers, leur abréviation, leur longueur en 1973 (en km, voir MAISCH 2001), la période et le nombre de mesures effectuées, la valeur des paramètres $\beta, Z$ and $\zeta$ du modèle ainsi que l'échelle temporelle. 


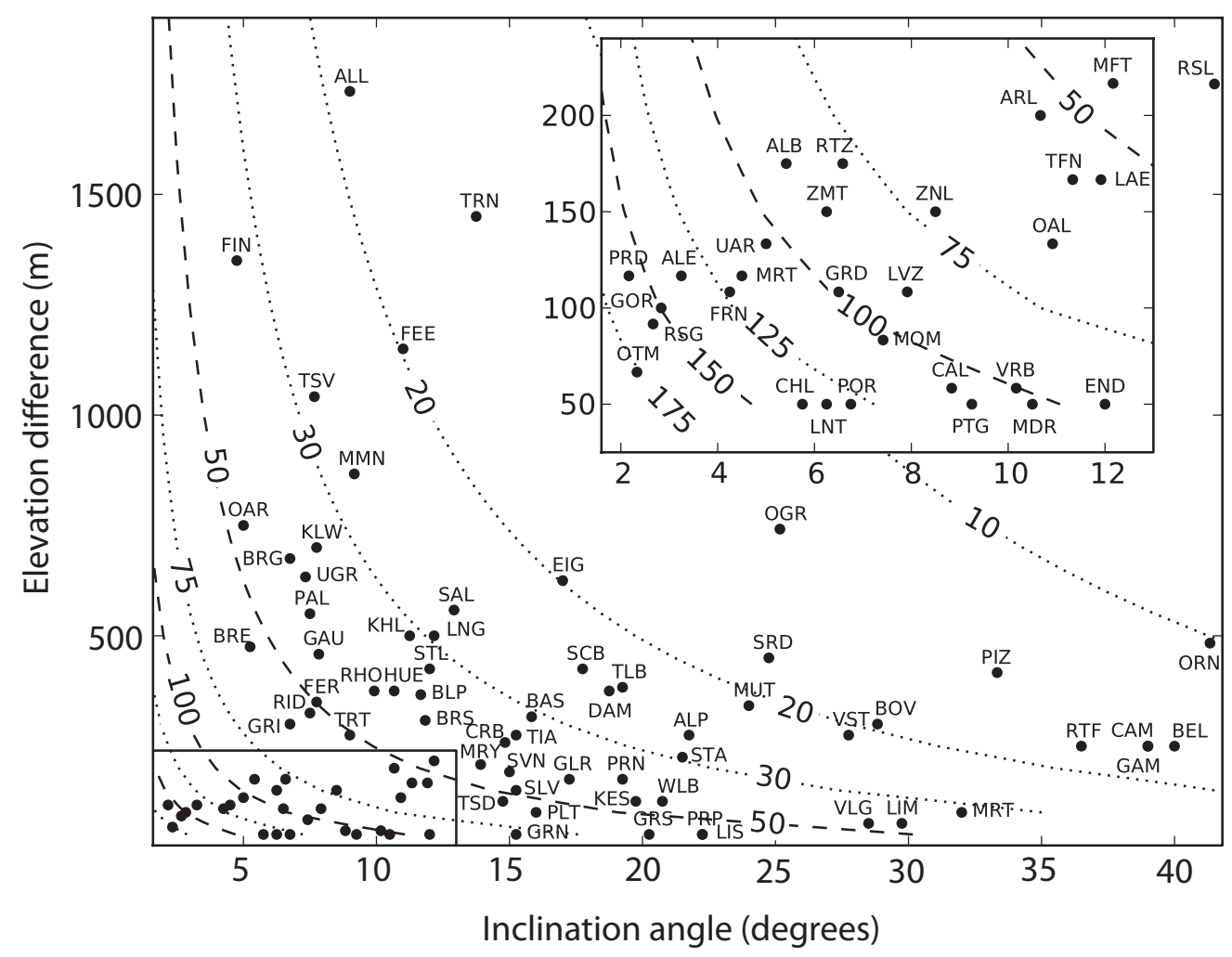

Fig. 6: Contours show volume time scale $\tau_{v}$ (in years) in dependence of bedrock inclination angle $\beta$ and vertical extent of the accumulation area $Z$. Parameter values of the best-fitting models are indicated with a dot for each glacier (3 letter abbreviation, cf. Table 1). Inset shows the enlargement of the lower left corner.

Konturen stellen die Volumenzeitskala $\tau_{v}$ (in Jahren) in Abhängigkeit von der Bettneigung $\beta$ und der Vertikalausdehnung $Z$ des Akkumulationsgebietes dar. Die Parameterwerte für die Modellgletscher mit der besten Übereinstimmung sind als Punkte dargestellt und mit dem Kürzel des Gletschernamens versehen (vgl. Tabelle 1). Die kleine Graphik ist ein vergrösserter Ausschnitt des unteren linken Bereiches.

Les contours montrent l'échelle de temps $\tau_{v}$ (en années) selon l'angle d'inclinaison du soubassement rocheux $\beta$ et l'extension verticale de la zone d'accumulation $Z$. Les valeurs des modèles les plus adaptés sont indiquées avec un point pour chaque glacier (pour les abréviations, voir Tableau 1). L'encart montre une vue agrandie du coin inférieur gauche.

of reduced incoming solar radiation caused by changes in total solar irradiance (STEINHILBER et al. 2009) and/or high volcanic dust concentrations in the atmosphere (e.g. CROWLEY 2000).

- Mass balance gradients are not constant in time. A step-wise change in mass balance gradient leads to a fast glacier tongue retreat due to enhanced melting, and a long-term advance when the increased mass gain has been transported from the accumulation area to the terminus. Since mass balance gradients change independent of ELA, it is very difficult to assess their relative importance.
The approach used above of lowering the ELA does not discern between the above possibilities, but corroborates the necessity of ELA changes during the LIA. The problem of explaining the LIA glacier mass gain with mass balance reconstructions based on temperature and precipitation has been discussed before (Nesje \& Dahl 2003; Vincent et al. 2005). It is not clear at present, whether such a disagreement can be explained by an increased winter precipitation within the inner Alpine region (as advocated by VINCENT et al. 2005), or due to other changes in climate parameters, such as an altered radiation budget. 


\section{Conclusions}

The glacier length change record of 91 glaciers from the Swiss Glacier Monitoring Network was analyzed with help of a macroscopic glacier model. By fitting modeled length changes to measurements, the parameters of the best-fitting model could be determined for each glacier. The measured length changes of all 91 glaciers can be explained with a single history of ELA variations. From the model parameters, the volume time scale can be determined, which ranges from 5 to 170 years, depending on inclination and vertical extent of the glaciers.

The glacier length change records cannot be interpreted by using an equilibrium line history based on reconstructed temperature and precipitation alone. During certain phases of the Little Ice Age (1650-1850) the ELA must have been lower by 100 to $200 \mathrm{~m}$, probably caused by increased winter precipitation, or by other changes in climate parameters such as reduced global radiation.

The proposed analysis of glacier length changes can be applied to other mountain ranges with similar data sets, and to longer glacier length change histories, and might thus be used to constrain the regional Alpine climate during the Little Ice Age.

\section{Acknowledgements}

This work was partially funded by the EU-FP7 project ACQWA (grant no. 212250).

\section{References}

CAsty, C., Wanner, H., Luterbacher, J., Esper, J. \& R. BöHм (2005): Temperature and precipitation variability in the European Alps since 1500. - In: International Journal of Climatology 25: 1855-1880, doi:10.1002/ joc.1216.

Clewley, R.H., Sherwood, W., LaMar, M. \& J. GuKKENHEIMER (2004): PyDSTool dynamical systems software. - http://pydstool.sourceforge.net 22.9.2009.

Crowley, T. (2000): Causes of climate change over the past 1000 years. - In: Science 289, 5477: 270-277.

Glaciological Reports (1881-2009): The Swiss Glaciers, 1880-2004/05. Technical Report 1-126, Yearbooks of the Cryospheric Commission of the Swiss Academy of Sciences (SCNAT), published since 1964 by the Laboratory of Hydraulics, Hydrology and Glaciology (VAW) of ETH Zurich, http://glaciology.ethz.ch/swissglaciers/.

Harrison, W.D., Elsberg, D.H., Echelmeyer, K.A. \& R.M. KRIMMEL (2001): On the characterization of glacier response by a single time-scale. - In: Journal of Glaciology 47, 159: 659-664.
Harrison, W.D., Raymond, C., Echelmeyer, K. \& R. Krimmel (2003): A macroscopic approach to glacier dynamics. - In: Journal of Glaciology 49, 164: 13-21.

Huss, M. (2009): Personal communication. - VAW, ETH Zurich and University of Fribourg.

Huss, M., Bauder, A., FunK, M. \& R. Hock (2008): Determination of the seasonal mass balance of four Alpine glaciers since 1865. - In: Journal of Geophysical Research 113, F01015.

Huss, M., FunK, M. \& A. Ohmura (2009): Strong alpine glacier melt in the 1940s due to enhanced solar radiation. - In: Geophysical Research Letters 36, L23501, doi:10.1029/2009GL040789.

Hutter, K. (1983): Theoretical glaciology: material science of ice and the mechanics of glaciers and ice sheets. - Dordrecht: D. Reidel Publishing Company, Tokyo: Terra Scientific Publishing Company.

Jóhannesson, T., Raymond, C.F. \& E.W. WaddingTON (1989): Time-scale for adjustment of glaciers to changes in mass balance. - In: Journal of Glaciology 35, 121:355-369.

KloK, E. \& J. Oerlemans (2003): Deriving historical equilibrium-line altitudes from a glacier length record by linear inverse modelling. - In: The Holocene 13, 3: 343-351.

LÜTHI, M.P. (2009):Transient response of idealized glaciers to climate variations. - In: Journal of Glaciology 55, 193: 918-930.

Maisch, M. (2001): Characteristics and retreat of the Swiss measurement network glaciers since 1850. - In: Herren, E.R., Hoelzle, M. \& M. Maisch (eds): The Swiss glaciers 1997/98 and 1998/99. Volume 119/120 of Glaciological Report: 43-52.

Nesje, A. \& S.O. Dahl (2003): The «Little Ice Age» - only temperature? - In: The Holocene 13, 1:139-145, doi:10.1191/0959683603hl603fa.

NYE, J.F. (1963): On the theory of the advance and retreat of glaciers. - Geophysical Journal of the Royal Astonomical Society 7, 4:431-456.

NyE, J.F. (1965a): The frequency response of glaciers. - In: Journal of Glaciology 5, 41:567-587.

NYE, J.F. (1965b): A numerical method of inferring the budget history of a glacier from its advance and retreat. - In: Journal of Glaciology 5, 41:589-607.

Oerlemans, J. (2001): Glaciers and climate change. - Leiden: Balkema Publishers.

Oerlemans, J. (2005): Extracting a climate signal from 169 glacier records. - In: Science 308, 5477: 270-277, doi:2010.1126/science.1107046.

Oerlemans, J. (2007): Estimating response times of Vadret da Morteratsch, Vadret da Palü, Briksdalsbreen and Nigardsbreen from their length records. - In: Journal of Glaciology 53, 182: 357-362.

Ohmura, A., Kasser, P. \& M. FunK (1992): Climate at the equilibrium line of glaciers. - In: Journal of Glaciology 38, 130: 397-411.

Steiner, D., Pauling, A., Nussbaumer, S.U., Nesje, A., 
Luterbacher, J., WANNER, H. \& H.J. ZumbÜHL (2008): Sensitivity of European glaciers to precipitation and temperature - two case studies. - In: Climatic Change 90: 413-441, doi:10.1007/s10584-008-9393-1.

Steiner, D., Walter, A. \& H. ZumbüHl (2005): The application of a non-linear back-propagation neural network to study the mass balance of Grosse Aletschgletscher, Switzerland. - In: Journal of Glaciology 51, 173: 313-323.

Steinhilber, F., Beer, J. \& C. Fröhlich (2009): Total solar irradiance during the Holocene. - In: Geophysical Research Letters 36, L19704, doi:10.1029/ 2009 GL040142.

Vincent, C., Le Meur, E., Six, D. \& M. Funk (2005): Solving the paradox of the end of the Little Ice Age in the Alps. - In: Geophysical Research Letters 32, L09706, doi:10.1029/2005GL022552.

\section{Abstract: Analysis of Alpine glacier length change records with a macroscopic glacier model}

The length change record of 91 glaciers in the Swiss Alps was analyzed with a novel macroscopic glacier model (LV-model). Based on a history of equilibrium line variations, synthetic length change data were calculated. From the LV-models matching best the measured length changes, characteristic parameters were obtained. The volume time scale thus determined ranges from 5 to 170 years for glaciers of different slope and length. The analysis shows that the observed glacier length changes cannot be reproduced with an equilibrium line variation based on temperature and precipitation alone. The equilibrium line has to be lowered by 100 to 200 meters during several phases of the Little Ice Age (in the time span 1650 to 1850) to obtain observed glacier responses. Such an effect might be attributable to either higher winter precipitation in the Alps, or to radiation forcing.

Keywords: glacier, climate, Alps, length change, dynamical system

\section{Zusammenfassung: Analyse der Längenänderungen von Alpengletschern mit einem makroskopischen Gletschermodell}

Die Längenänderungen von 91 Gletschern der Schweizer Alpen wurden mit einem neuartigen makroskopischen Gletschermodell (LV-Modell) analysiert. Ausgehend von einer Geschichte von Höhenänderungen der Gleichgewichtslinie wurden Längenänderungen berechnet. Das LV-Modell mit der besten Übereinstimmung mit gemessenen Längenänderungen ermöglicht die Bestimmung charakteristischer Grössen, aus denen die Volumenzeitskala bestimmt werden kann. Je nach Neigung und Länge variiert diese zwischen fünf und 170 Jahren. Die Methode zeigt, dass sich die gemessenen Längenänderungen nicht reproduzieren lassen, wenn die Änderungen der Gleichgewichtslinie nur von den rekonstruierten Temperaturen und Niederschlägen abhängen. Die Gleichgewichtslinie muss während verschiedener Phasen der «Kleinen Eiszeit» (1650 bis 1850) um 100 bis 200 Meter tiefer gelegen haben, um die beobachtete Reaktion der Gletscher zu erklären. Ein solcher Effekt könnte entweder auf höhere Winterniederschläge in den Alpen oder auf eine geringere Strahlung zurückzuführen sein.

Schlüsselwörter: Gletscher, Klima, Alpen, Längenänderung, dynamische Systeme

\section{Résumé: Analyse des variations de longueur des glaciers suisses: un modèle glaciaire macroscopique} Nous avons analysé les mesures des variations de longueur de 91 glaciers des Alpes suisses au moyen d'un nouveau modèle glaciaire macroscopique (modèle LV). Nous avons calculé des données synthétiques de variations de longueur de glaciers sur la base d'une série se rapportant aux altitudes de la ligne d'équilibre pour les années passées. En adaptant au mieux le modèle LV aux données des variations de longueur, nous avons obtenu des paramètres propres à chaque glacier. L'échelle de temps obtenue pour les différents glaciers varie entre 5 et 170 années suivant la pente et la longueur des glaciers. Notre analyse a montré que les variations de longueur observées ne peuvent être expliquées par des fluctuations de la ligne d'équilibre basées sur les températures et les précipitations. L'altitude de la ligne d'équilibre a dû être abaissée de 100 à 200 mètres durant certaines périodes du Petit Âge glaciaire (entre 1650 et 1850) pour obtenir les variations observées sur les glaciers. Cet effet peut être attribué soit à des précipitations plus élevées dans les Alpes, soit à une radiation solaire réduite.

Mots-clés: glacier, climat, Alpes, changement de longueur, système dynamique

Dr. Martin P. Lüthi, Dr. Andreas Bauder, Laboratory of Hydraulics, Hydrology and Glaciology (VAW), Swiss Federal Institute of Technology (ETH) Zurich, CH-8092 Zurich, Switzerland.

e-mail:

luethi@vaw.baug.ethz.ch

bauder@vaw.baug.ethz.ch

\section{Manuskripteingang/received/manuscrit entré le 12.1.2010}

Annahme zum Druck/accepted for publication/accepté pour l'impression: 9.7.2010 